\title{
Flood control at km 130 Padaleunyi Toll
}

\author{
Suci Anggraeni ${ }^{1, *}$, Arno Adi Kuntoro², Mohammad Farid ${ }^{2}$, Dhemi Harlan $^{2}$, and M. Bagus Adityawan ${ }^{2}$ \\ ${ }^{1}$ Study Program of Water Resources Management, Faculty of Civil and Environmental Engineering, Institut Teknologi Bandung, \\ Bandung, Indonesia \\ ${ }^{2}$ Water Resources Engineering Research Group, Faculty of Civil and Environmental Engineering, Instiut Teknologi Bandung, \\ Bandung, Indonesia
}

\begin{abstract}
Flood is one of the natural phenomena that often brings loss of property and life. Mostly, it occurs during a high-intensity rainfall event in the catchment area which results in high river flow that cannot be accommodated by river cross sections. In Bandung area, one of the locations that are often hit by the flood is located on $\mathrm{km} 130$ of the Padaleunyi toll road. This flood occurred due to the overflow of the Cilember and/or Cimancong rivers tributary which flows parallel to the toll road, inundating the toll road segment with low elevation at around $\mathrm{km} 130+500$. This paper aims to analyze the effective flood control methods in the above location. With catchment area around $2.3 \mathrm{~km} 2$, which is relatively small, peak flood discharge calculation was carried out using a rational method. Hydraulics simulation was carried out using HecRas, based on river field measurement data of Cilember and Cimancong river cross-section. Analysis result shows that the combination between flood embankment construction and river normalization provides a significant decrease in flood water level in $\mathrm{km} 130$ Padaleunyi toll road. The reinforced concrete vertical wall was considered as the appropriate flood protections structure due to the limited space available between the river and the toll road segment. This paper also underlined the impact of the increasing loss of water retention areas on an increased risk of flooding.
\end{abstract}

\section{Introduction}

Based on historical floods at KM 130 Padaleunyi Toll in November 2016 and October 2017 there was a flood along the toll with overflowing points originating from the Cimancong River. The main cause of the overflow of water in the Cimancong River is the intensity of rain that occurs in the upstream is very large and the infiltration capacity of the area is small. This condition can be seen from the land use of the surrounding area which was originally filled with rice fields and gardens turned into landfills, as well as a flat-topped watershed topography, the elevation between the Cimancong River and the Padaleunyi Toll has a value not much different so that the rise in the Cimancong River can easily overflow on the road without being infiltrated into the soil properly.

Flood events on KM 130 Padaleunyi toll cause great losses, such as disruption of road traffic which results in total congestion on the left and right sections of the Padalarang and Cileunyi toll. This loss must be controlled and addressed by integrated flood damage mitigation efforts in the form of a reduction in peak flood discharge, reduction/transfer of water discharge in a body of water, flood resistance with infrastructure, flood warning, and floodplain processing. With this flood, control effort is expected to reduce the impact of losses caused by the overflow of the Cimancong river

\section{Location description}

Cimancong watershed which extends from coordinates $6^{\circ} 55^{\prime} 22.5^{\prime \prime} \mathrm{S} ; 107^{\circ} 32^{\prime} 46.7^{\prime \prime} \mathrm{E}$ to $6^{\circ} 53^{\prime} 47.6^{\prime \prime} \mathrm{S} ; 107^{\circ} 33^{\prime} 37^{\prime \prime} \mathrm{E}$ and has an outlet point located at coordinates $6^{\circ} 55^{\prime} 22.5$ "S; $107^{\circ} 32^{\prime} 46.7^{\prime \prime E}$. This watershed has an area of about $2.3 \mathrm{~km}^{2}$ with land cover consisting of industrial areas, residential area, gardens, parks and rice fields. Cimancong watershed is located in an area with an elevation of about 700 - 710 meters above sea level and is included in a fairly densely populated area.

Accessibility of the study location can be reached through the Padalarang-Cimahi residential area, where the location of this study is parallel to the toll road towards Padalarang-Cileunyi. The picture 1 shows the Cimancong:

\footnotetext{
* Corresponding author: Sucianggraeni755@gmail.com
} 


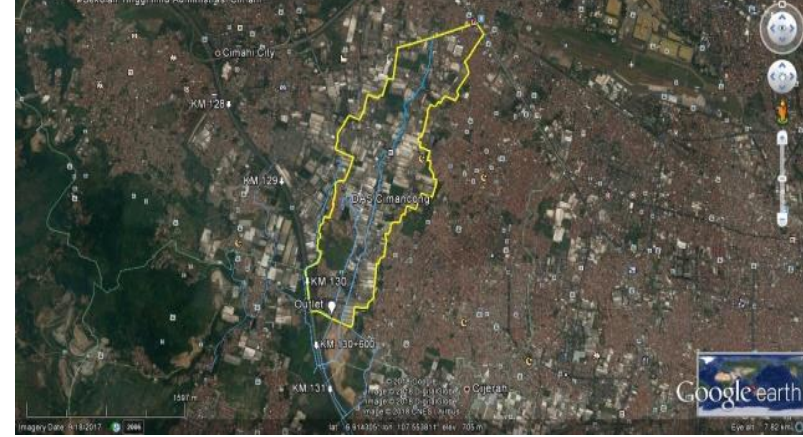

Fig. 1. Cimancong Watershed

\section{Data and method}

\subsection{Data}

Data used in generating trends are observation data on rainfall from BMKG. The influential rain station was Bandung Climatology Station with the length of rain data used throughout 37 years from 1980 to 2016.

\subsection{Method}

In general, the method used is as follow

- Collection the data and information

- Hydrological Analysis

- Calculate Watershed with generate in google earth based on elevation area.

- Calculate the Rainfall Area with Polygon Thieseen Method.

With

$$
R=\frac{A 1 \cdot R 1+A 2 \cdot R 2+A n \cdot R n}{A 1+A 2+A 3+\cdots A n}
$$

$\mathrm{R} \quad$ : Average rainfall height $(\mathrm{mm})$

$\mathrm{R} 1, \mathrm{Rn} \quad$ : High rainfall at each station

$\mathrm{A} 1, \mathrm{An} \quad$ : Area at each station $\left(\mathrm{km}^{2}\right)$

- Calculate Frequency Analysis to produce the rainfall design estimate with calculating the frequency analysis with Gumbel Type I Method, Log Pearson Type III Method, Normal Method, Log Normal Log Method. The results of the frequency analysis were then tested by the Smirnov-Kolmogorof and Chi Square.

- Gumbel Type I method

$$
X T=X+K T \cdot S d
$$

$K t=-\frac{\sqrt{6}}{\pi}\left[0.5772+\ln \left(\ln \frac{T}{T-1}\right)\right]$

With

$\mathrm{Xt}$ : Rainfall Design Estimate with data measuring $\mathrm{T}$ years Period $(\mathrm{mm})$

$\mathrm{X}$ : Average rainfall ( $\mathrm{mm})$

$\mathrm{Sd} \quad$ : Standard deviation of rainfall

$\mathrm{Kt}$ : Frequency factor

$\mathrm{P} \quad$ : Probability of occurrence

- $\quad$ Log Pearson Type III

With.

$$
\log X T=\log X+K T \cdot S d_{\log x}
$$

Xt : Rainfall Design Estimate with data measuring $\mathrm{T}$ years Period ( $\mathrm{mm}$ )

$\mathrm{X}$ : Average rainfall $(\mathrm{mm})$

$\mathrm{Sd}$ : Standard deviation of rainfall

$\mathrm{Kt}$ : Frequency factor

$\mathrm{P} \quad$ : Probability of occurrence

- $\quad$ Log Normal Method

With.

$$
\log X T=\log X+K T \cdot S d_{\log x}
$$

Xt : Rainfall Design Estimate with data measuring $\mathrm{T}$ years Period (mm)

$\mathrm{X}$ : Average rainfall $(\mathrm{mm})$

$\mathrm{Sd} \quad$ : Standard deviation of rainfall

$\mathrm{Kt}$ : Frequency factor

$\mathrm{P} \quad$ : Probability of occurrence

- $\quad$ Normal Method

With.

$$
X T=X+K T . S d
$$

Xt : Rainfall Design Estimate with data measuring $\mathrm{T}$ years Period $(\mathrm{mm})$

$\mathrm{X}$ : Average rainfall $(\mathrm{mm})$

$\mathrm{Sd}$ : Standard deviation of rainfall

$\mathrm{Kt}$ : Frequency factor

$\mathrm{P} \quad$ : Probability of occurrence

- $\quad$ Chi Square Method

With.

$$
X^{2}=\sum_{i=1}^{n} \frac{(O i-E i)^{2}}{E i}
$$

X2 : The value of Chi Square is calculated

Oi : Number of observations in the i-group

Ei : Number of theoritical values in the $\mathrm{i}$ subgroup.

$\mathrm{N}$ : Amount of data

- Kolmogorov- Smirnov Method

With.

$$
D n=\max |P(x)-P(o)|
$$

$\mathrm{Dk}=$ Vertical / maximum distance between observation and theoretical

$\mathrm{P}(\mathrm{x})=$ Probability of the sample data

$\mathrm{P}(\mathrm{o})=$ Probability of the theoretical

- Calculate the Effective Rainfall

The effective rainfall distribution that is used is based on Van Dreen

$$
I=\frac{90 \% X T}{4}
$$

With.

I : Rainfall Intensity $(\mathrm{mm} / \mathrm{hr})$

Xt : Rainfall Design Estimate with data measuring $\mathrm{T}$ years Period

- Flood Discharge Estimate

The planned flood discharge is calculated using the Synthetic Unit Hydrograph Method which is the Nakayasu Method, SCS and empiric method, which is a practical Rational Method.

$$
Q p=0.00278 \text { C.I.A }
$$


With.

Qp : Peak flood discharge $\left(\mathrm{m}^{3} / \mathrm{s}\right)$

C : Coefficient of flow

I : Rainfall Intensity $(\mathrm{mm} / \mathrm{hr})$

A : Area of flow $\left(\mathrm{km}^{2}\right)$

- Hydraulical Analysis

Hydraulical analysis using software HEC-RAS 1d at the existing condition and the 25 year periode with the input data are river geometry, flood discharge estimate, and boundary conditian .

\section{Hydrological analysis}

\subsection{Rainfall design estimate}

In the hydrological analysis, the influential rain station was Bandung Climatology Station with the length of rain data used throughout 37 years from 1980 to 2016 . From the rain data, then calculating the frequency analysis with Gumbel Type I Method, Log Pearson Type III Method, Normal Method, Log Normal Method. The results of the frequency analysis were then tested by the SmirnovKolmogorof and Chi Square tests. The results of the two distribution tests show that the chosen method is the Log Pearson Type III Method. The amount of rainfall planned as shown in Table 1 below:

Table 1. Rainfall with $\mathrm{T}$ years periode

\begin{tabular}{|c|c|}
\hline T - Year Periode & Rainfall (mm) \\
\hline 200 & 133 \\
\hline 100 & 125 \\
\hline 50 & 118 \\
\hline 25 & 110 \\
\hline 10 & 99 \\
\hline 5 & 90 \\
\hline 2 & 77 \\
\hline
\end{tabular}

\subsection{Effective rainfall}

In the calculation of effective rainfall, it is assumed that infiltration has no effect this is due to the area of the watershed that is small enough so that it can be concluded that the amount of effective rainfall is the amount of rainfall that occurs. The amount of effective rainfall as shown in Table 2 below:

Table 2. Effective rainfall

\begin{tabular}{|c|c|c|}
\hline \multirow{2}{*}{$\begin{array}{c}\text { T - Year } \\
\text { Periode }\end{array}$} & \multicolumn{2}{|c|}{ Rainfall (mm) } \\
\cline { 2 - 3 } & $\begin{array}{c}\text { Design } \\
\text { Estimate }\end{array}$ & Effective \\
\hline 100 & 125 & 125 \\
\hline 50 & 118 & 118 \\
\hline 25 & 110 & 110 \\
\hline
\end{tabular}

\begin{tabular}{|c|c|c|}
\hline \multirow{2}{*}{$\begin{array}{c}\text { T - Year } \\
\text { Periode }\end{array}$} & \multicolumn{2}{|c|}{ Rainfall (mm) } \\
\cline { 2 - 3 } & $\begin{array}{c}\text { Design } \\
\text { Estimate }\end{array}$ & Effective \\
\hline 10 & 99 & 99 \\
\hline 5 & 90 & 90 \\
\hline 2 & 77 & 77 \\
\hline
\end{tabular}

The rain that is used for calculation is the effective rainfall value that has been distributed in hours. The effective rainfall distribution that is used is based on Van Dreen investigation where one day of rain is only focused in 4 hours with a large amount of uniform rainfall for each hour. The following Figure 2 explains the effective distribution of rainfall in the $\mathrm{T}$ year period.

Distribution of Effective Rainfall

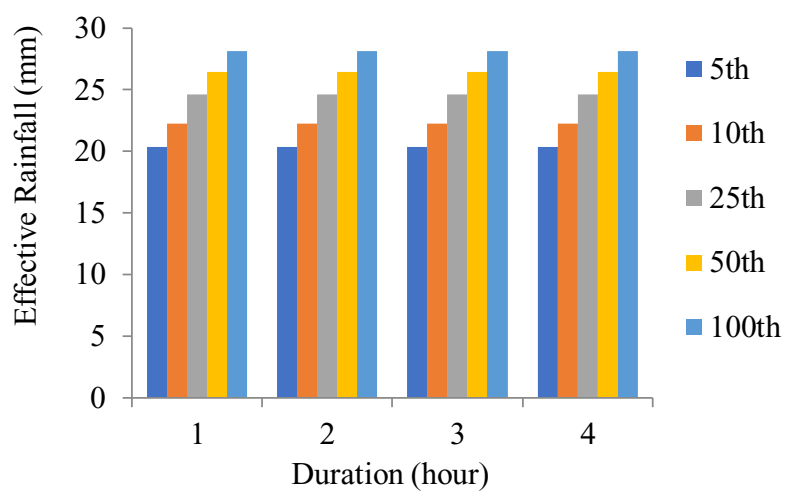

Fig. 2. Distribution of effective rainfall

\subsection{Flood discharge}

The planned flood discharge is calculated using the Synthetic Unit Hydrograph Method which is the Nakayasu Method, SCS and empiric method, which is a practical Rational Method. Based on the consideration of calibration of bankfull discharge, the flood discharge value used is the result of the calculation of the Rational Method. As for the equations used in the calculation of the practical Rational method are. Figure 3 presents the flood discharge plan with a T-year period.

Flood Discharge

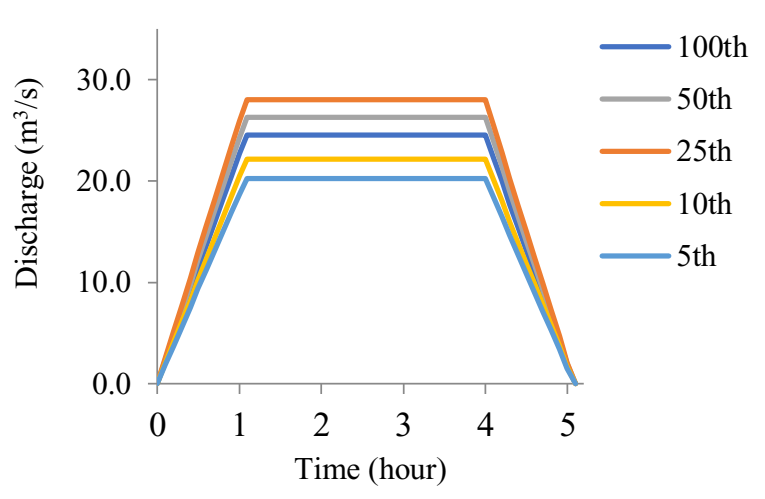

Fig. 3. Flood discharge 
In planning flood control buildings in a city with a population more than $2,000,000,000$ of people, using flood discharge during the 25 th periode of $24.25 \mathrm{~m}^{3} / \mathrm{sec}$ with a peak discharge time of about 1.1 hours.

\section{Hydraulical analysis}

Hydraulic analysis when existing conditions is using 1dimensional HEC-RAS software. River geometry input from STA 0 - STA 19 tends to be straight and the simulation discharge is using Q25. The Figure 4-6 shows the river geometry input, cross and long-sectional view of the river after running:

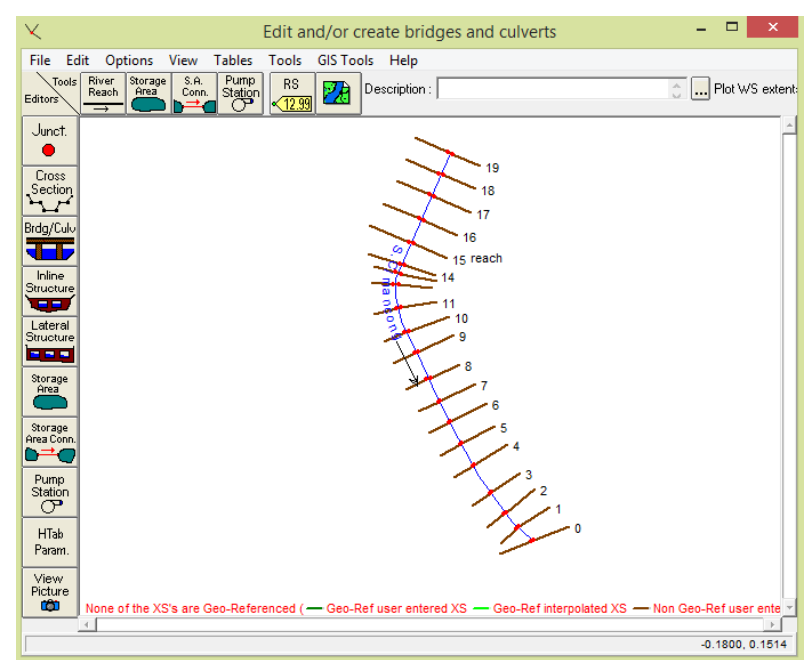

Fig. 4. Geometry of Cimancong River

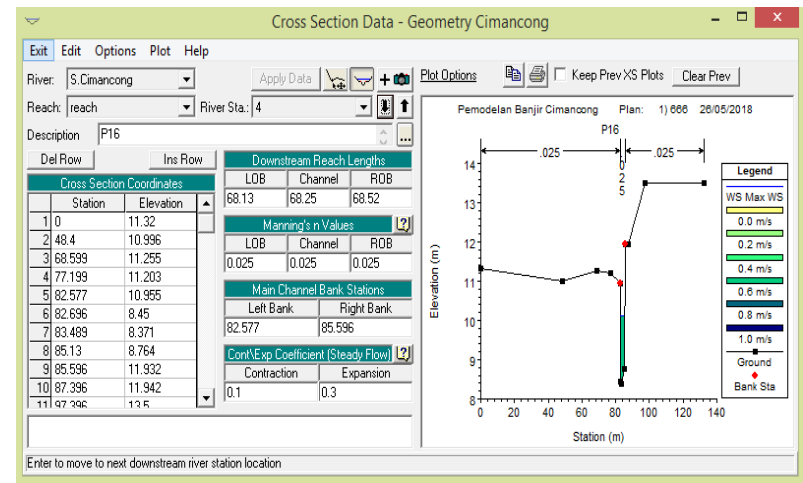

Fig. 5. Cross section of Cimancong River after running

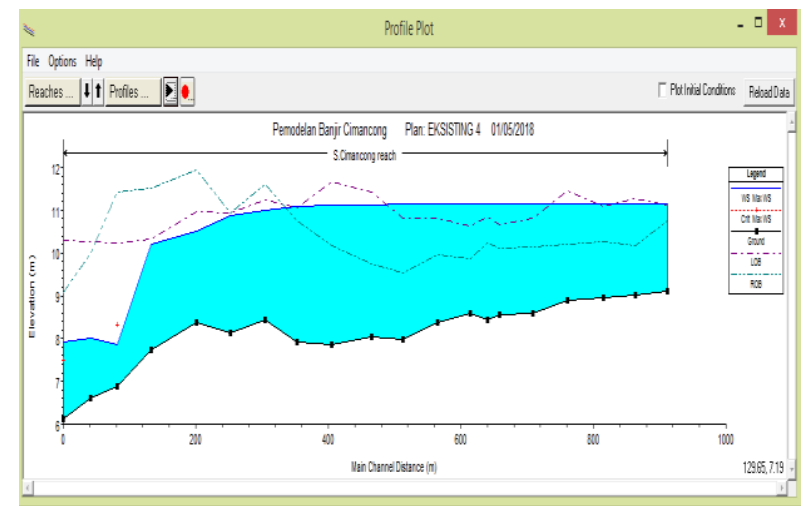

Fig. 6. Long-section of Cimancong River
From the figure above, it can be seen that the river cross-section at Sta-9, Sta-10, Sta-11, Sta-12, Sta-13, Sta-14, StA-15, Sta-16, Sta-17, Sta-18, and Sta- 19 occurs overtopping / overflow of water. This happens because the cross section of the river is not able to accommodate the flow of water when a planned flood discharge occurs.

In the display figure extends the condition of the Cimancong River above, it is known that a sudden decrease in water level at Sta-1, this condition is caused by the influence of the superkirits flow $(\mathrm{Fr}>1)$ where the channel slope is steeper than the critical slope, causing flow at Sta -1 has acceleration and has an effect on the water level in the cross section

\section{Alternative flood control}

\subsection{Alternative 1: Normalization of the river}

Normalization of the river is planned with several considerations, including: developer activities in the form of reclamation, land acquisition factors, the best and safest hydra-section and border line considerations. Normalization planning is carried out with a uniform trapezoid on STA 0 - STA 8, and the non-uniform trapezoid on STA 9 - STA 19. The illustration of normalization planning in the (a) upstream and (b) downstream sections as follows on Figure 7:

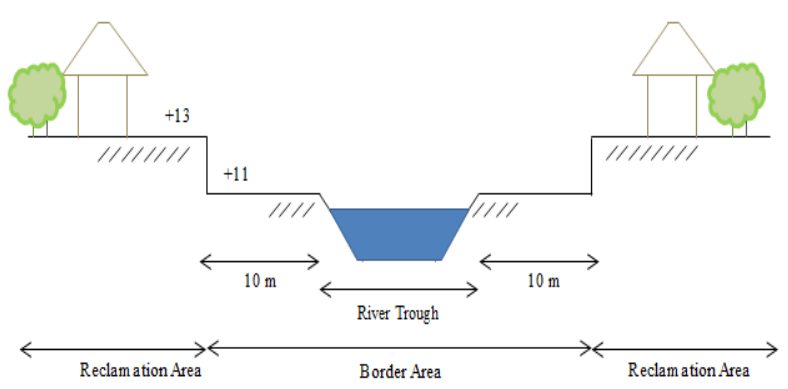

(a)

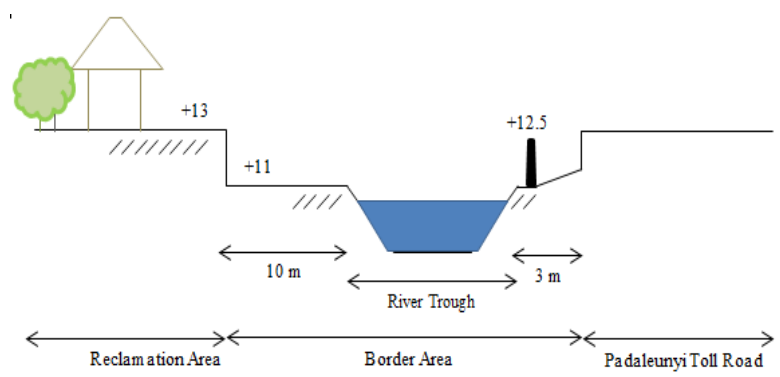

(b)

Fig. 7. Ilustration of normalization planning

Then simulated using the help of HEC-RAS software and input data discharge about Q25 has result a cross and longitudinal display as follows on Figure 8-9: 


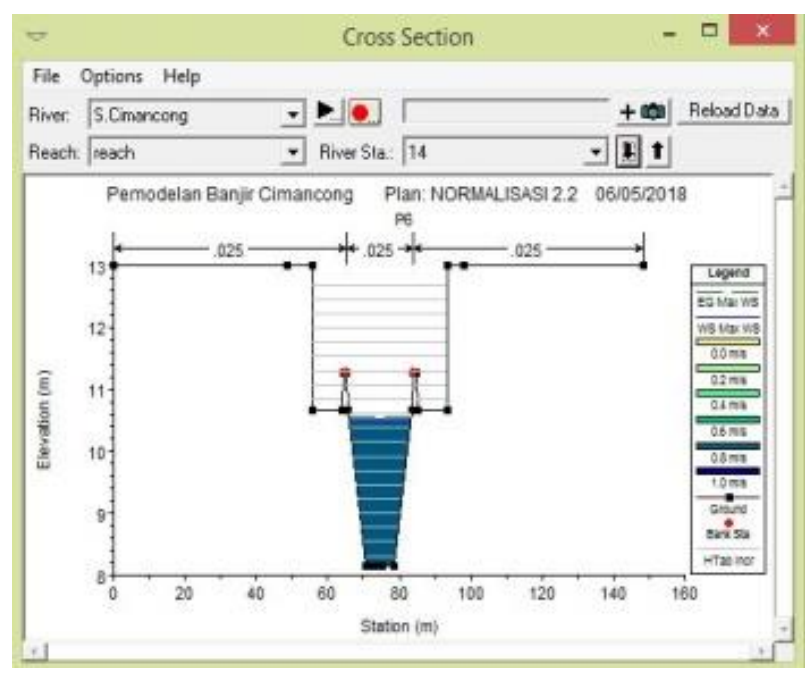

Fig. 8. Cross-section (P.14) of Cimancong River

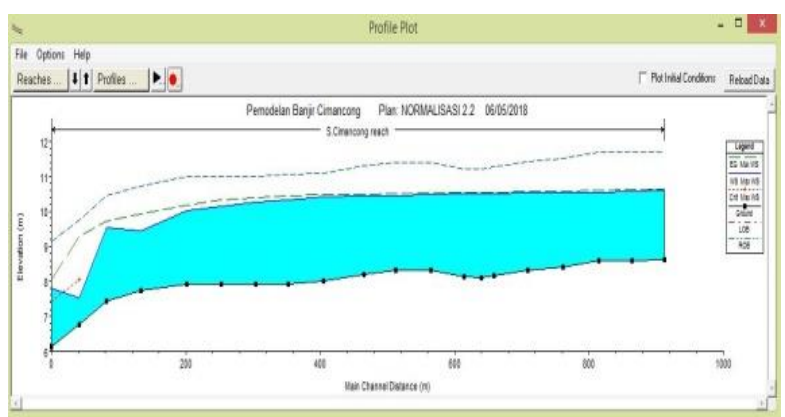

Fig. 9. Long-section of Cimancong River

The Table 3-4 explains that normalization planning is able to be a flood solution and safe with the dimention of freeboard used, and based on the calculation of slope stability in STA 4, STA 7, and STA 9, the results are safe for the possibility of landslides throughout the planning.

Table 3. Result calculation of slope stability

\begin{tabular}{|c|c|c|c|}
\hline $\begin{array}{c}\text { River } \\
\text { STA- }\end{array}$ & Condition & $\begin{array}{c}\text { without } \\
\text { earthquake }\end{array}$ & $\begin{array}{c}\text { with } \\
\text { earthquake }\end{array}$ \\
\hline \multirow{3}{*}{ STA-16 } & Flood & 14.36 & 9.84 \\
\cline { 2 - 4 } & Dry & 11.4 & 8.76 \\
\cline { 2 - 4 } & Critical & 10.39 & 7.94 \\
\hline \multirow{3}{*}{ STA-13 } & Flood & 7.86 & 5.23 \\
\cline { 2 - 4 } & Dry & 5.61 & 4.42 \\
\cline { 2 - 4 } & Critical & 5.23 & 4.11 \\
\hline \multirow{3}{*}{ STA-10 } & Flood & 6.42 & 4.02 \\
\cline { 2 - 4 } & Dry & 4.7 & 3.53 \\
\cline { 2 - 4 } & Critical & 3.97 & 3.01 \\
\hline
\end{tabular}

Table 4. Result calculation of normalization planning

\begin{tabular}{|c|c|c|c|c|c|c|c|}
\hline $\begin{array}{c}\text { River } \\
\text { Sta- }\end{array}$ & $\begin{array}{l}\text { Cross } \\
\text { Section }\end{array}$ & $\begin{array}{l}\text { Flood } \\
\text { Water } \\
\text { Level }\end{array}$ & $\begin{array}{c}\text { Elevation at } \\
\text { the top of the } \\
\text { trough right } \\
\text { side }\end{array}$ & $\begin{array}{c}\text { Elevation at } \\
\text { the top of the } \\
\text { trough left } \\
\text { side }\end{array}$ & $\begin{array}{c}\Delta \mathrm{H} \text { right } \\
\text { side }\end{array}$ & $\begin{array}{c}\Delta \mathrm{H} \text { left } \\
\text { side }\end{array}$ & $\begin{array}{c}\text { Freeboard } \\
=0.6 \mathrm{~m}\end{array}$ \\
\hline & & (m) & (m) & (m) & (m) & (m) & \\
\hline 19 & $\mathrm{Pl}$ & 10.59 & 11.305 & 11.305 & 0.715 & 0.715 & fulfilled \\
\hline 18 & $\mathrm{P} 2$ & 10.56 & 11.3 & 11.3 & 0.74 & 0.74 & fulfilled \\
\hline 17 & P3 & 10.55 & 11.301 & 11.301 & 0.751 & 0.751 & fulfilled \\
\hline 16 & P4 & 10.54 & 11.319 & 11.319 & 0.779 & 0.779 & fulfilled \\
\hline 15 & P5 & 10.52 & 11.221 & 11.221 & 0.701 & 0.701 & fulfilled \\
\hline 14 & P6 & 10.52 & 11.262 & 11.262 & 0.742 & 0.742 & fulfilled \\
\hline 13 & P7 & 10.51 & 11.21 & 11.21 & 0.7 & 0.7 & fulfilled \\
\hline 12 & P8 & 10.5 & 11.222 & 11.222 & 0.722 & 0.722 & fulfilled \\
\hline 11 & P9 & 10.48 & 11.405 & 11.405 & 0.925 & 0.925 & fulfilled \\
\hline 10 & P10 & 10.45 & 11.4 & 11.4 & 0.95 & 0.95 & fulfilled \\
\hline 9 & P11 & 10.45 & 11.3 & 11.3 & 0.85 & 0.85 & fulfilled \\
\hline 8 & P12 & 10.41 & 11.1 & 11.1 & 0.69 & 0.69 & fulfilled \\
\hline 7 & $\mathrm{P} 13$ & 10.32 & 11.06 & 11.06 & 0.74 & 0.74 & fulfilled \\
\hline 6 & P14 & 10.26 & 11.01 & 11.01 & 0.75 & 0.75 & fulfilled \\
\hline 5 & $\mathrm{P} 15$ & 10.14 & 11.01 & 11.01 & 0.87 & 0.87 & fulfilled \\
\hline 4 & P16 & 10.02 & 11.01 & 11.01 & 0.99 & 0.99 & fulfilled \\
\hline 3 & P17 & 9.44 & 10.728 & 10.728 & 1.288 & 1.288 & fulfilled \\
\hline 2 & P18 & 9.54 & 10.432 & 10.432 & 0.892 & 0.892 & fulfilled \\
\hline 1 & P19 & 7.54 & 9.758 & 9.758 & 2.218 & 2.218 & fulfilled \\
\hline 0 & $\mathrm{P} 20$ & 7.79 & 9.136 & 9.136 & 1.346 & 1.346 & fulfilled \\
\hline
\end{tabular}

\subsection{Alternative 2: Construction of Embankments}

Construction of embankments is planned with a number of considerations, including: developer activities in the form of reclamation, land loading factors, safe dimensions of sliding, rolling, and soil carrying capacity as well as border line considerations. Construction of embankments is carried out along STA 5 - STA 13 on right side of the river with the provision of peak elevation at each point of embankment are same. The following on Figure 10 is an illustration of the planning of embankment development at the study location:

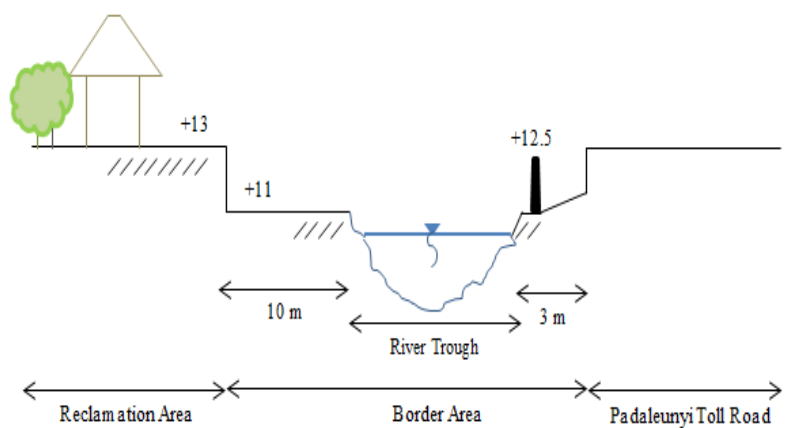

Fig. 10. Ilustration of construction of embankments planning

Then simulated using the help of HEC-RAS software with a cross and longitudinal display as follows on Figure 11-12: 


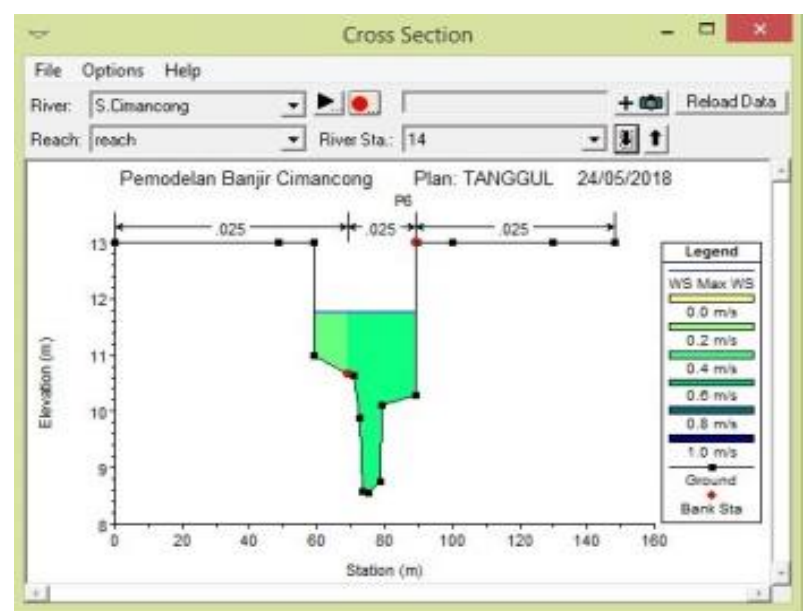

Fig. 11. Cross-section (P14) of Cimancong River

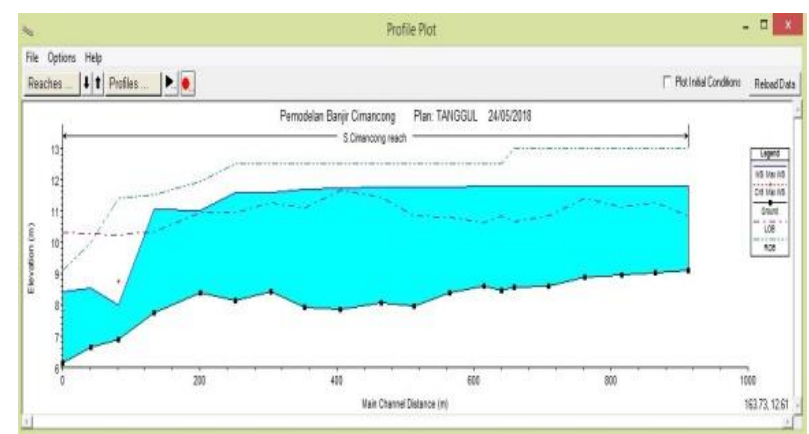

Fig. 12. Long-section of Cimancong River

The Table 5-6 explains that normalization planning is able to be a flood solution and safe with the dimention of freeboard used, and based on the calculation of slope stability, the results are safe for the possibility of landslides throughout the planning:

Table 5. Result Calculation of construction of Embankment

\begin{tabular}{|c|c|c|c|c|c|c|}
\hline River Sta & $\begin{array}{c}\text { Cross } \\
\text { Section }\end{array}$ & $\begin{array}{c}\text { Flood Water } \\
\text { Level }\end{array}$ & $\begin{array}{c}\text { Elevation of } \\
\text { Embankment }\end{array}$ & $\begin{array}{c}\text { Elevation of } \\
\text { Reclamation } \\
\text { Land }\end{array}$ & $\Delta \mathbf{H}$ & $\begin{array}{c}\text { Freeboard }= \\
\mathbf{0 . 6} \mathbf{~ m}\end{array}$ \\
\hline & & $(\mathrm{m})$ & $(\mathrm{m})$ & $(\mathrm{m})$ & $(\mathrm{m})$ & \\
\hline 19 & P1 & 11.8 & & 13 & 1.2 & fulfilled \\
\hline 18 & P2 & 11.79 & & 13 & 1.21 & fulfilled \\
\hline 17 & P3 & 11.79 & & 13 & 1.21 & fulfilled \\
\hline 16 & P4 & 11.78 & & 13 & 1.22 & fulfilled \\
\hline 15 & P5 & 11.79 & & 13 & 1.21 & fulfilled \\
\hline 14 & P6 & 11.78 & & 13 & 1.22 & fulfilled \\
\hline $\mathbf{1 3}$ & P7 & $\mathbf{1 1 . 7 7}$ & $\mathbf{1 2 . 5}$ & & $\mathbf{0 . 7 3}$ & fulfilled \\
\hline $\mathbf{1 2}$ & P8 & $\mathbf{1 1 . 7 8}$ & $\mathbf{1 2 . 5}$ & & $\mathbf{0 . 7 2}$ & fulfilled \\
\hline $\mathbf{1 1}$ & P9 & $\mathbf{1 1 . 7 7}$ & $\mathbf{1 2 . 5}$ & & $\mathbf{0 . 7 3}$ & fulfilled \\
\hline $\mathbf{1 0}$ & $\mathbf{P 1 0}$ & $\mathbf{1 1 . 7 6}$ & $\mathbf{1 2 . 5}$ & & $\mathbf{0 . 7 4}$ & fulfilled \\
\hline $\mathbf{9}$ & $\mathbf{P 1 1}$ & $\mathbf{1 1 . 7 5}$ & $\mathbf{1 2 . 5}$ & & $\mathbf{0 . 7 5}$ & fulfilled \\
\hline $\mathbf{8}$ & $\mathbf{P 1 2}$ & $\mathbf{1 1 . 7 4}$ & $\mathbf{1 2 . 5}$ & & $\mathbf{0 . 7 6}$ & fulfilled \\
\hline $\mathbf{7}$ & $\mathbf{P 1 3}$ & $\mathbf{1 1 . 6 8}$ & $\mathbf{1 2 . 5}$ & & $\mathbf{0 . 8 2}$ & fulfilled \\
\hline $\mathbf{6}$ & $\mathbf{P 1 4}$ & $\mathbf{1 1 . 5 9}$ & $\mathbf{1 2 . 5}$ & & $\mathbf{0 . 9 1}$ & fulfilled \\
\hline $\mathbf{5}$ & $\mathbf{P 1 5}$ & $\mathbf{1 1 . 5 7}$ & $\mathbf{1 2 . 5}$ & & $\mathbf{0 . 9 3}$ & fulfilled \\
\hline 4 & P16 & 10.99 & & 11.93 & 0.94 & fulfilled \\
\hline 3 & P17 & 11.05 & & 11.71 & 0.66 & fulfilled \\
\hline 2 & P18 & 8 & & 11.41 & 3.41 & fulfilled \\
\hline 1 & P19 & 8.52 & & 9.99 & 1.47 & fulfilled \\
\hline 0 & P20 & 8.43 & & 9.08 & 0.65 & fulfilled \\
\hline
\end{tabular}

Table 6. Result calculation of slope stability

\begin{tabular}{|c|c|c|c|c|c|c|c|}
\hline \multirow{2}{*}{$\begin{array}{c}\text { Embank } \\
\text { ment }\end{array}$} & \multicolumn{2}{|c|}{ SLIDING } & \multicolumn{2}{c|}{ ROLLING } & \multicolumn{3}{c|}{ Soil Bearing Cpacity } \\
\cline { 2 - 8 } & $\begin{array}{c}\text { with } \\
\text { earthquake }\end{array}$ & $\begin{array}{c}\text { without } \\
\text { earthquake }\end{array}$ & $\begin{array}{c}\text { with } \\
\text { earthquake }\end{array}$ & $\begin{array}{c}\text { without } \\
\text { earthquak } \\
\text { e }\end{array}$ & q limit & q max & q min \\
\hline STA-13 & 1.4 & 1.2 & 1.94 & 1.85 & 331.78 & 71.47 & 4.09 \\
\hline STA-10 & 2.05 & 1.65 & 1.83 & 1.81 & 350.9 & 79.09 & 4.013 \\
\hline
\end{tabular}

\subsection{Alternative 3: Construction of Embankments and normalization of Cimancong River}

Construction of embankments and river normalization is planned with several considerations, including: developer activities in the form of reclamation, land acquisition factors, safe dimensions of sliding, rolling, and soil carrying capacity as well as border line considerations. Construction of embankments is carried out along STA 5 - STA 13 on the right side of the river with the provision of peak elevation at each point of embankment are same, and normalization of the river is carried out along STA 0 - STA 4. The following on Figure 13 is an illustration of the study location planning in (a) embankments planning and (b) normalization planning:

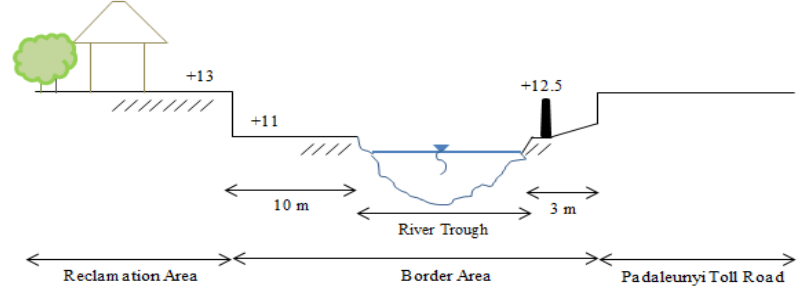

(a)

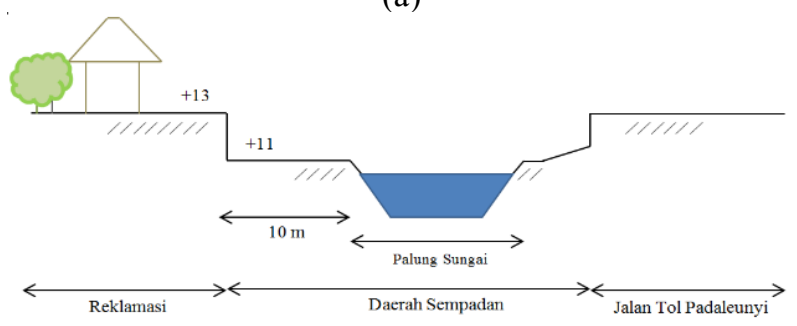

(b)

Fig. 13. Ilustration of construction of embankments and normalization planning

Then simulated using the help of HEC-RAS software with a cross and longitudinal display as follows on Figure 14-15:

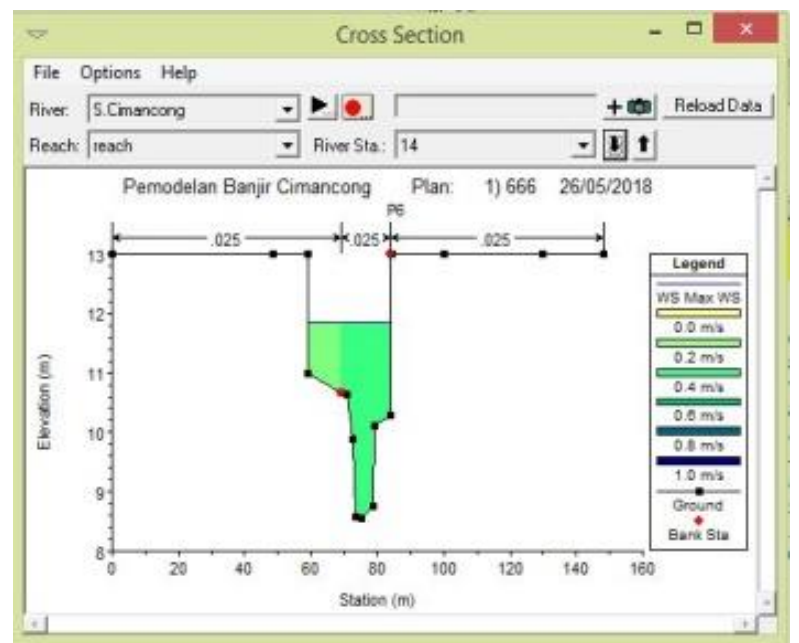

Fig. 14. Cross-section of Cimancong River 


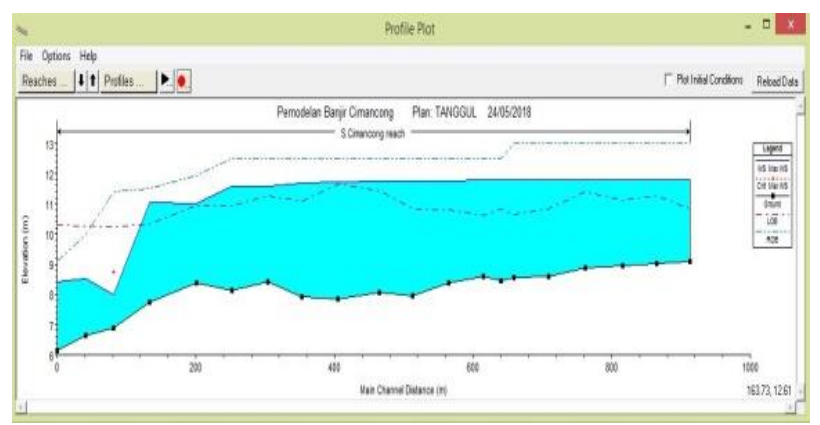

Fig. 15. Long-section of Cimancong River

The table explains that alternative is able to be a flood solution:

Table 7. Result Calculation of construction of embankment and normalization planning

\begin{tabular}{|c|c|c|c|c|c|c|c|}
\hline $\begin{array}{l}\text { River } \\
\text { Sta- }\end{array}$ & $\begin{array}{l}\text { Cross } \\
\text { Section }\end{array}$ & $\begin{array}{l}\text { Flood } \\
\text { Water } \\
\text { Level }\end{array}$ & $\begin{array}{c}\text { Elevation of } \\
\text { Embankment }\end{array}$ & $\begin{array}{l}\text { Elevation at the top of } \\
\text { the trough right side } \\
\text { (Normalization Area) }\end{array}$ & $\begin{array}{c}\text { Elevation of } \\
\text { Soil }\end{array}$ & $\Delta \mathrm{H}$ & $\begin{array}{c}\text { Freeboard }=0.6 \\
\mathrm{~m}\end{array}$ \\
\hline & & (m) & (m) & & (m) & (m) & \\
\hline 19 & $\mathrm{Pl}$ & 11.48 & & & 13 & 1.52 & Fulfilled \\
\hline 18 & P2 & 11.47 & & & 13 & 1.53 & Fulfilled \\
\hline 17 & P3 & 11.46 & & & 13 & 1.54 & Fulfilled \\
\hline 16 & P4 & 11.45 & & & 13 & 1.55 & Fulfilled \\
\hline 15 & P5 & 11.45 & & & 13 & 1.55 & Fulfilled \\
\hline 14 & P6 & 11.43 & & & 13 & 1.57 & Fulfilled \\
\hline 13 & P7 & 11.43 & 12 & & & 0.6 & Fulfilled \\
\hline 12 & P8 & 11.43 & 12 & & & 0.6 & Fulfilled \\
\hline 11 & $\mathrm{P9}$ & 11.41 & 12 & & & 0.6 & Fulfilled \\
\hline 10 & P10 & 11.39 & 12 & & & 0.61 & Fulfilled \\
\hline 9 & P11 & 11.37 & 12 & & & 0.63 & Fulfilled \\
\hline 8 & P12 & 11.35 & 12 & & & 0.65 & Fulfilled \\
\hline 7 & $\mathrm{P} 13$ & 11.02 & 12 & & & 0.98 & Fulfilled \\
\hline 6 & P14 & 10.14 & 12 & & & 1.86 & Fulfilled \\
\hline 5 & P15 & 10.36 & 12 & & & 1.64 & Fulfilled \\
\hline 4 & $\mathrm{P} 16$ & 9.55 & & 11.0 & & 1.46 & Fulfilled \\
\hline 3 & $\mathrm{P} 17$ & 9.43 & & 11.0 & & 1.58 & Fulfilled \\
\hline 2 & P18 & 9.41 & & 11.0 & & 1.6 & Fulfilled \\
\hline 1 & P19 & 7.52 & & 10.7 & & 3.2 & Fulfilled \\
\hline 0 & $\mathrm{P} 20$ & 7.73 & & 10.4 & & 2.7 & Fulfilled \\
\hline
\end{tabular}

\section{Conclusion}

Conclusions for planning flood control buildings at KM 130 Padaleunyi Toll are as follows:

1. Problems that occur in the Cimancong River and cause flooding in KM 130 Padaleunyi Toll which is caused by the cross section of the river that is not able to accommodate the water load during a flood.

2. To solve the problem of flooding at KM 130 Padaleunyi Toll will be planned to build embankments with reinforced concrete structures on the right side of the river channel that intersect with toll roads, from Sta-5 to Sta-13 or $413 \mathrm{~m}$.

3. Planning embankment dimensions using flood discharge during the 25th periode of $24.25 \mathrm{~m} 3 / \mathrm{sec}$ and $0.6 \mathrm{~m}$ freeboard, and plan dimensions are safe against shear, rolling and soil bearing stability. Accessibility of the study location can be reached through the Padalarang-Cimahi residential area, where the location of this study is parallel to the toll road towards Padalarang-Cileunyi. The picture 1 shows the Cimancong:

\section{References}

1. V. T. Chow, Hidraulik Saluran Terbuka (1998).

2. B. M. DAS, Mekanika Tanah (Prinsip-Prinsip Rekaya Geoteknis) Jilid 2 (1995)

3. B. M. DAS, Principle of Foundation Engineering Seventh Edition (1995)

4. R. D. Anchoe, Design of Liquid Retaining Concrete Structure Second Edition (1992)

5. C. D. Soemarto, Hidrologi Teknik (1990)

6. S. Soedarsono, Takeda, Hidrologi untuk Pengairan (1993)

7. Suripin, Sistem Drainase Perkotaan yang Berkelanjutan (2004)

8. B. Triatmojo, Hidraulika II (1995)

9. B. Triatmojo, Hidrologi Terapan (2008) 